\title{
ПРИНЦИПИ, МЕТОДИ ТА ГАЛУЗІ МЕДИКО-БІОЛОГІЧНИХ ЗАСТОСУВАНЬ ОПТИЧНИХ ІМУНОСЕНСОРІВ
}

\author{
В. П. Марценюк, А. Клос-Вітковска, \\ А. С. Сверстюк ${ }^{1}$, Т. В. Бігуняк ${ }^{1}$ \\ Університет Бєльсько-Бяли, Республіка Польща \\ ${ }^{1}$ ДВНЗ «Тернопільський державний медичний університет \\ імені І. Я. Горбачевського МОЗ України»
}

\begin{abstract}
Стаття присвячена дослідженню основних принципів проектування та фрізико-біологічних методів використання оптичних імуносенсорів. Ми досліджуємо основні шляхи застосування оптичних імуносенсорів у біології та медицині, включаючи тестування якості харчових продуктів, захист природного середовища, медичну діагностику.
\end{abstract}

Ключові слова: біосенсор, імуносенсор, флуоресценція, поглинання.

\section{ON PRINCIPLES, METHODS AND AREAS OF MEDICAL AND BIOLOGICAL APPLICATION OF OPTICAL IMMUNOSENSORS}

\section{P. Martsenyuk, A. Klos-Witkowska,} A. S. Sverstiuk ${ }^{1}$, T. V. Bihunyak ${ }^{1}$

University of Bielsko-Biala, the Republic of Poland

${ }^{1}$ SHEE «l. Horbachevsky Ternopil State Medical University

of the Ministry of Health of Ukraine»

\begin{abstract}
The article is devoted to research of the basic principles of design and physical and biological methods of use of optical immunosensors. We investigate the main application of optical immunosensors in biology and medicine including testing food quality, natural environment protection, medical diagnostics.
\end{abstract}

Key words: biosensor, optical immunosensor, fluorescence, absorbance.

\section{ПРИНЦИПЫ, МЕТОДЫ И ОТРАСЛИ МЕДИКО-БИОЛОГИЧЕСКИХ ПРИМЕНЕНИЙ ОПТИЧЕСКИХ ИММУНОСЕНСОРОВ}

\author{
В. П. Марценюк, А. Клос-Витковска, \\ А. С. Сверстюк ${ }^{1}$, Т. В. Бигуняк ${ }^{1}$ \\ Университет Бельско-Бялы, Республика Польша

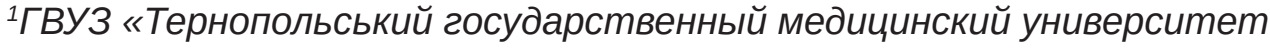 \\ имени И. Я. Горбачевского МЗ Украины»
}

\begin{abstract}
Статья посвящена исследованию основных принципов проектирования и фризико-биологических методов использования оптических иммуносенсоров. Мы исследуем основные пути применения оптических иммуносенсоров в биологии и медицине, включая тестирование качества пищевых продуктов, защиту окружающей среды, медицинскую диагностику.
\end{abstract}

Ключевые слова: биосенсор, иммуносенсор, фрлуоресценция, поглощение. 
Introduction. The history of biosensors began in 1956, when Leland C. Clark Jr., called the «father of biosensors», invented the first sensor - an oxygen electrode. In 1962, Clark described the first amperometric biosensor, which was an enzyme electrode for glucose [28]. Since then, biosensors have become the subject of intense research, stimulating interest and imagination of scientists $[17,18,27$, 29]. In the years 1972-1975, for the first time, a biosensor, named after a commercial scale, was introduced Yellow Springs Instruments, which was used to determine glucose. Retail sales of biosensors for a single analyte were successful [8], which contributed to the huge popularity of biosensors in the last years. The development of technology made it possible to construct more and more perfect and more technologically advanced devices (including macro- to micro- and nanoscale).

Biosensor is defined as a device used to detect a biological analyte occurring in an environment or biological origin (e. g. found in the human body) [14]. According to IUPAC (International Union of Pure and Applied Chemistry) it is a self-sufficient integrated device that is able to provide specific, quantitative or semi-quantitative analytical information by means of recognized biological element (biochemical receptor) that remains indirect spatial contact with the electrochemical conductive element.

Depending on the area of application, biosensors may have different definitions and terminologies (e. g. immunosensors, glucometers, biochips, biocomputers, etc.).

Due to the type of transducer, biosensors are distinguished [15, 20]: 1) electrochemical (using potentiometric, amperometric or impedymetric transducers for converting biological information in a measurable signal), 2) optical, 3) acoustic wave, 4) thermal, 5) based on microvisors.

The purpose of the article is to research the basic principles of design and physical and biological methods of use of optical immunosensors and their application.

Mechanisms of interaction and methods of detecting light substances inimmunosensors. The optical immunosensors monitor optical changes resulting from the interactions with the analyte. These changes are caused by light-matter interactions: absorption, reflectance, dispersion or emission.

Mechanisms of interaction and methods of detecting light substances inimmunosensors are presented in table 1 due to [15].

Detection methods used in optical immunosensors. UV/VIS absorption spectroscopy - spectroscopy that enables imaging of electron transitions from the ground state to the excited state in a molecule, that are related to changes in vibrational and rotational energy. The range of electromagnetic spectrum used in this spectroscopy is $200-1100 \mathrm{~nm}$. Measurements are usually made with a transparent medium, while absorbance changes are caused by an analyte.

Table 1

Mechanisms of interaction and methods of detecting light substances inimmunosensors

\begin{tabular}{|c|c|c|}
\hline $\begin{array}{l}\text { Mechanism of light- } \\
\text { matter interaction }\end{array}$ & Detection techniques & Description of methods \\
\hline Absorbance & $\begin{array}{l}\text { Ultraviolet/Visible (UV/VIS) } \\
\text { spectroscopy }\end{array}$ & $\begin{array}{l}\text { This method uses electromagnetic radiation (200- } \\
1100 \mathrm{~nm}) \text {. Absorbance changes are caused by the } \\
\text { interaction with an analyte. Measurements are made } \\
\text { in a transparent medium }\end{array}$ \\
\hline Reflectance & $\begin{array}{l}\text { Reflectometric interference } \\
\text { spectroscopy. Surface plasmon } \\
\text { resonance (SPR) }\end{array}$ & $\begin{array}{l}\text { The technique based on white light interference in } \\
\text { thin films. Analyte binding changes the reflection } \\
\text { coefficient, thus directly alters also the product } \\
\text { Ln, where n- is reflection coefficient and L is film } \\
\text { thickness. The method uses the reflection coefficient } \\
\text { of very thin films of materials absorbed in a metal }\end{array}$ \\
\hline Dispersion & $\begin{array}{l}\text { Optical wave guide light-mode } \\
\text { spectroscopy }\end{array}$ & $\begin{array}{l}\text { The technique based on measurements of the } \\
\text { resonant polarization angle of laser light scattered } \\
\text { from the grating and coupled with a thin film } \\
\text { wave guide. This methods allows the thickness of } \\
\text { absorber to be measured }\end{array}$ \\
\hline Emission & Fluorescence spectroscopy & $\begin{array}{l}\text { The method for measuring fluorescence intensity, } \\
\text { lifetime, energy transfer between donor and acceptor }\end{array}$ \\
\hline
\end{tabular}


Absorbance measurements made by employing UV/ VIS spectroscopy were used for developing a new type of immunosensors designed for tracking antibiotic residues.

Optical wave guide light-mode spectroscopy is a technique based on measurements of the resonant polarization angle of laser light scattered from the grating and coupled with a thin film wave guide.

With this technique it is possible to determine the thickness of the absorber layer. This method was used to improve low-detection limit immunosensors (compared to traditional immunological tests for detecting: herbicide active ingredient triflualin, fusarium mycotoxin zearalenone, egg yolk protein and vitellogenin (Vtg) [22].

One of very sensitive method that uses reflection of light is reflectometric interference spectroscopy. This method is based on white light interference in thin films. Through analyte binding the reflection coefficient from the film is changed, thus also the product $\mathrm{nL}$, where $\mathrm{n}$ is reflection coefficient and $\mathrm{L}$ is film thickness [3]. This technique was employed to determine the porous alumina (pAl2O3) film inimmunosensors that use simple protein and two antibodies (immunoglobulin G (IgG)) [3] .

SPR is an optical technique for measuring reflection coefficient of very thin films of materials absorbed by metals [5].

Fluorescence spectroscopy is one of the most common research methods in studies of immunosensors, although this method requires the presence of fluorophores that can be natural or artificial (created by fluorescent labeling of a non-fluorescent molecules). This technique allows fluorescence intensity, lifetime, or energy transfer between donor and acceptor to be measured.

According to [30], optical immunosensors can be divided into three groups: 1 ) direct monitoring sensors (without immunoreaction labels), 2) sensors that detect compounds labeled inimmunoreactions (fluorescent labeled compounds), 3) sensors that measure products of immunological reactions.

Optical immunosensors in medical application. Optical immunosensors are specified a labelfree fiber-optic Fabry - Perot interferometric immunosensoris proposed by layer-by-layer selfassembly of a suspended chitosan and polystyrene sulfonate membrane at the tip of a hollow fiber. IgG was immobilized on the polyelectrolyte substrate and the detection of target anti-immunoglobulin G (antiIgG) was monitored through the measurement of substrate's effective optical thickness. The sensitivity and specificity of the sensor were studied using correlated and non-correlated anti-IgG/IgG pair. Sensitivity of $0.033 \mu \mathrm{m} /(\mathrm{pg} / \mathrm{mm} 2)$ and limit of detection of $0.005 \mathrm{nM}$ was achieved with the sensor displaying minimal response toward non-correlated anti-IgG. The results demonstrate the feasibility of the sensor for immunosensing [10].

According to the article "Development of fluorescence change-based, reagent-less optic immunosensor" by Satoka Aoyagi and Masahiro Kudo, a reagentless, regenerable and portable optic immunosensor was developed. A model sample, IgG, was detected with this system based on changes in fluorescent intensity of fluorescent labeled protein A with specific reactivity to IgG depending on a reaction between the proteins [6].

A glass plate immobilized with Qdot ${ }^{\mathrm{TM}}$-labeled protein A was placed on the top of optic fibers designed for both excitation and fluorescence emission. The optic fibers with the Qdot ${ }^{\mathrm{TM}}$-labeled protein A-immobilized glass plate were inserted into a solution of pH 7.4 phosphate buffered saline. After stabilization of the fluorescence intensity, IgG was added and the time-course of the fluorescence intensity was measured on a fluorometer connected with the optic fibers. Furthermore, the fluorescence response of a transient state was evaluated with the same system. When the Qdot-labeled protein A bound to IgG, fluorescence intensity decreased because of the inhibition by IgG. The degree of fluorescence decrease depends on the IgG concentration at a steady state and also in a transient state.

In [16] label-free, all-fiber immunosensors based separately on Mach-Zehnder interferometry (MZI) and Michelson interferometery (MI) implemented using only single mode fiber (SMF) are proposed and experimentally demonstrated. The proposed SMF-MZI and SMF-MI sensors rely on intermodal interference between the core mode and cladding modest detect ambient refractive index changes due to protein absorption on the cladding-ambient interface. The fiber surfaces were functionalized with self-assembled polyelectrolyte layers (chitosan / polysodium styrene sulfonate). IgG was immobilized on the polyelectrolyte layer and anti-IgG molecular binding events were monitored through measurement of wave length shifts. The proposed immunosensors exhibitant IgG detection sensitivities of $27.37 \mathrm{~nm} /$ (ng/mm2) and $5.91 \mathrm{~nm} /(\mathrm{ng} / \mathrm{mm} 2)$ with concentration detection limits of $0.181 \mathrm{nM}$ and $4.941 \mathrm{nM}$ for MZI and MI sensor respectively. The specificities 
of the sensors were investigated using correlated / non-correlated anti-IgG - IgG pairs. These results demonstrate the feasibility of these sensors for various bio/chemical applications such as DNA hybridization detection and immunosensing.

Some immunosensors have developed a sensitive photonic crystal fiber (PCF)-based immunosensor for detection of alpha-fetoprotein (AFP). The unique PCF possesses a morphology characterized by numerous pore structures and a large surface area-to-volume ratio, which can be used as an immune-reaction carrier to improve the sensitivity and reaction speed of AFP detection. The PCF-based immunosensor possesses a low limit of detection of $0.1 \mathrm{ng} / \mathrm{mL}$, which is five times lower than that of the capillary-based sensor and 35 times lower than that of the traditional enzyme-linked immunosorbent assay. The wide linear dynamic range of $0.1-150 \mathrm{ng} / \mathrm{mL}$ makes the developed immunosensor suitable for clinical practice. The proposed method was successfully applied to AFP detection in a clinical serum sample with acceptable precision. It is indicated that the present PCF-based immunosensor could be used as an attractive analytical platform for sensitive and specific detection of cancer biomarkers [24].

A selective fiber-optic-based immunosensor for haptens is described and characterized. In order to construct a sensor for different analytes, a prescribed reaction protocol is followed and only the recognition element [F( $\left.a b^{\prime}\right)$ antibody fragment] has to be changed. The dynamic range of this sensor is about two orders of magnitude and the detection limits are at least $25 \mathrm{nM}$ (25- $\mu$ l volume) [12]. By using steady-state fluorescence and classical ultra-high-vacuum surface analytical techniques, the effects of regeneration media, reaction and storage times and interferents on the sensor response were studied.

Portable fiber-optic immunosensor based on competitive immunoreactions between coating-haptens and free haptens in solutions with corresponding antibodies, was developed to determine the concentration of the free hapten, methsulfuron-methyl. The ovalbumin-methsulfuron-methyl conjugate was immobilized on a microscope slide. Horse radish peroxidase labeled goat anti-rabbit IgG was used to generate an optical signal. The portable optical device consisted of a $0.25 \mathrm{~W}$ tungsten halogen light source and a photosensitive diode detector. A typical competitivebinding calibration curve was seen between 0.3 and $100 \mathrm{ng} / \mathrm{ml}$ of methsulfuron-methyl. The detection limit for methsulfuron-methyl was $0.1 \mathrm{ng} / \mathrm{ml}$ [26].
There is the fiber optics evanescent field based biosensor as an excellent candidate for label-free detection of cardiac biomarkers that are of great importance in rapid, early, and accurate diagnosis of acute myocardial infarction. In that paper, they report a compact and sensitive cardiac troponin I (cTn-I) immunosensor based on the phase-shifted microfiber Bragg grating probe which is functionalized. The fine reflective signal induced by the phase shift in modulation significantly improves the spectral resolution, enabling the ability of the sensor in perceiving an ultra-small refractive index change due to the specific capture of the cTn-I antigens. In buffer, a log-linear sensing range from 0.1 to $10 \mathrm{ng} / \mathrm{mL}$ and a limit of detection of $0.03 \mathrm{ng} / \mathrm{mL}$ (predicted to be as low as $10.8 \mathrm{pg} / \mathrm{mL}$ ) are obtained. Furthermore, with good specificity, the sensor can be applied in test of cTn-I in human serum samples [2]. The proposed sensor presents superiorities such as improved integratability and portability, easy fabrication and operation, and intrinsic compatibility to the fiber-optic network, and thus has a promising prospect in "point-of-care" test for cardiac biomarkers and preclinical diagnosis.

An acousto-optict unable filter-surface plasmon resonance (AOTF-SPR) immunosensor based on wave length-modulation was applied to detect fibronectin by direct, sandwich and colloidal $\mathrm{Au}-$ enhanced immunoassay. The design of the wave length-modulation AOTF-SPR immunosensor is based on fixing the incident angle of light and measuring the reflected intensity of light in the wave length range spanning 440-790 nm. Fibronectin was determined in the concentration range 2.5-30, $0.5-30$, and $0.25-30 \mu \mathrm{g} / \mathrm{mL}$ for direct, sandwich and colloidal Au-enhanced immunoassay, respectively. The results demonstrate that AOTF-SPR biosensor can be applied to direct and enhanced immunoassay of biomolecule [1].

The main scheme of the cell for measuring as well as the sensor device itself, the analysis conditions and the results of quantitative determination of several antigens such as estradiol-17, $\alpha$-2-interferon, chorionic honadotropine, antibodies to the influenza virus, total IgG and cells of Salmonella typhimurium are presented. Special attention is given to immobilization of one of the immunocomponents on the fiber optic surface [13]. The sensitivity of the fiber optic immunosensors intended for determination of the abovementioned substances was comparable with that of the ELISA method, but in all cases the rate of analysis using the immunosensors was much faster. 
The evanescent wave fiber immunosensors (EWFI) technique was developed for the real-time rapidly sensitive and specific detection of the monoclonal antibody 3E2 of bluetongue virus (BTV). The outercore protein VP7 of BTV was labled on the surface of the exposed fiber-optic core. The monoclonal antibody 3E2 of BTV VP7 were added and then the goat ant-rat IgG conjugated with Cy3 was captured. After the $532 \mathrm{~nm}$ pulse (excitation source) reached the fiber probe, evanescent wave was generated, which excited the Cy3 bound to the immuno-complex and produced the fluorescent signal, which was changed into electrical signals read through computer. The preliminary results suggested that a detection limit of $10 \mathrm{ng} / \mathrm{ml}$ was measured for the monoclonal antibody $3 \mathrm{E} 2$, which is equal to the sensitivity of ELISA. The 3E2 sample was specifically detected through the EWFI assay in $15 \mathrm{~min}$, and the fiber can be recycled at least ten times through TEA solution condition. This developed EWFI was a real-time rapidly sensitive and specific way for the detection of BTV antibodies [9].

The EWFI technique was developed for the realtime rapidly sensitive and specific detection of the monoclonal antibody 3E2 of BTV. The outer-core protein VP7 of BTV was labeled on the surface of the exposed fiber-optic core. The monoclonal antibody 3E2 of BTV VP7 were added and then the goat antrat IgG conjugated with Cy3 was captured. After the $532 \mathrm{~nm}$ pulse (excitation source) reached the fiber probe, evanescent wave was generated, which excited the Cy3 bound to the immunocomplex and produced the fluorescent signal, which was changed into electrical signals read through computer. The preliminary results suggested that a detection limit of $10 \mathrm{ng} / \mathrm{ml}$ was measured for the monoclonal antibody $3 E 2$, which is equal to the sensitivity of ELISA. The 3E2 sample was specifically detected through the EWFI assay in $15 \mathrm{~min}$, and the fiber can be recycled at least ten times through TEA solution condition [9]. This developed EWFI was a real-time rapidly sensitive and specific way for the detection of BTV antibodies.

Optical immunosensors for determination of quality of food and beverages. Valerii Myndrul et al. [25] said "a rapid and low cost photoluminescence (PL) immunosensor for the determination of low concentrations of Ochratoxin A (OTA) has been developed". This immunosensor was based on porous silicon (PSi) and modified by antibodies against OTA (anti-OTA). Psi layer was fabricated by metalassisted chemical etching procedure. Main structural parameters (pore size, layer thickness, morphology and nanograins size) and composition of Psi were investigated by means of X-ray diffraction, scanning electron microscopy and Raman spectroscopy. PL-spectroscopy of Psi was performed at room temperature and showed a wide emission band centered at $(680 \pm 20) \mathrm{nm}$. Protein A was covalently immobilized on the surface of PSi, which in next steps was modified by anti-OTA and bovine serum albumin (BSA) in this way a anti-OTA/Protein-A/Psi structure sensitive towards OTA was designed. The anti-OTA/Protein-A/PSi-based immunosensors were tested in a wide range of OTA concentrations from $0.001 \mathrm{up}$ to $100 \mathrm{ng} / \mathrm{ml}$. Interaction of OTA with antiOTA/Protein-A/Psi surface resulted in the quenching of photoluminescence in comparison to bare PSi. The limit of detection and the sensitivity range of antiOTA/Protein-A/Psi immunosensors were estimated. Association constant and Gibbs free energy for the interaction of anti-OTA/Protein-A/Psi with OTA were calculated and analyzed using the interaction isotherms. Response time of the anti-OTA/Protein-A/ PSi-based immunosensor toward OTA was in the range of 500-700 s. These findings are very promising for the development of highly sensitive, and potentially portable immunosensors suitable for fast determination of OTA in food and beverages.

In [4] OTA as one of the most widespread and dangerous food contaminants was considered. Rapid, label-free and precise detection of low OTA concentrations requires novel sensing elements with advanced bio-analytical properties. They presented photoluminescence (PL) based immunosensor for the detection of OTA. During the development of immunosensor photoluminescent $\mathrm{ZnO}$ nanorods (ZnO-NRs) were deposited on glass substrate. Then the $\mathrm{ZnO}-\mathrm{NRs}$ were silanized and covalently modified by Protein-A (Glass/ZnO-NRs/Protein-A). The latest structure was modified by antibodies against OTA (Anti-OTA) in order to form OTA-selective layer (Glass/ZnO-NRs/Protein-A/Anti-OTA). In order to improve immunosensors selectivity the surface of Glass/ZnO-NRs/Protein-A/Anti-OTA was additionally blocked by BSA. Formed Glass/ZnO-NRs/Protein-A/ BSA\&Anti-OTA structures were integrated within portable fiber optic detection system, what is important for the development to flow cost and portable immunosensors.

The principle of a competitive immunoassay was employed for the development of an optical immunosensor for pesticide analysis. Triazines were assayed using fluorescence labeled antibodies. 
On one end of a hard clad silica fiber, which was stripped of cladding, a derivative of the s-triazines, aminohexylatrazine, was immobilized. The fiber was inserted in a flow through cuvette. Triazine antibodies conjugated with fluoresce in isothiocyanate were detected after binding to the fiber surface by the fluorescence coupled into the fiber via the evanescent field. In the presence of triazines the fluorescence signal decreases due to the inhibition of antibody binding to the fiber. The detection limit of the sensor for terbutryn was $0.1 \mathrm{ng} / \mathrm{ml}$ (obtained using a monoclonal antibody). This is the maximum concentration of a single pesticide which may be present in drinking water, according to European Community regulations [31].

In [19] a sensitive, simple and rapid detection of trace amounts of melamine in milk products was achieved in a reusable, portable optical sensor system based on the principle of immunoassay and evanescent waveexcited fluorescence. The EWFI employed a singlemultimode fiber optic coupler for light excitation and collection of fluorescence generated from the fiber optic probe. A reusable immunosurface of fiber probe was established to allow the performance of more than 300 assay cycles. Each assay cycle was less than 15 min.

Application of optical immunosensors for natural environment protection. One of the greatest challenges that define the performance of a fiber optic biosensor is the immobilization of the bioreceptor molecules onto the surface of fiber optic. A photoinducible silanediazirine was developed as an effective cross linker in the construction of a chemiluminescent immunosensor targeting a model E. coli analyte. After optimization, it has shown superior adaptability over traditional chemiluminescent ELISA and a commonly used glutaraldehyde chemical immobilization method in detection limit $\left(6.44 \times 10^{2} \mathrm{CFU} / \mathrm{ml}\right)$ and dynamic range $\left(6.44 \times 10^{5}\right.$ to $6.44 \times 10^{8} \mathrm{CFU} / \mathrm{ml}$, $\mathrm{r}^{2}=0.98 ; 6.4 \times 10^{2}$ to $6.44 \times 10^{5}, \mathrm{r}^{2}=0.92$ ). The newly developed immobilization method has enhanced the function of fiber optic biosensor as an affordable and dispatchable tool in the early warning monitoring of the putative presence of E. coli cells. It can be used either in individual sample screening or incontinuous monitoring of the environment to indicate the need for further investigation [23]. The diazirine cross linking method canals be adopted in the immobilization of other protein-based bioentities thus expanding its real-world utility.

Fiber-optic sensors based on the excitation of luminescent chromophores by the evanescent field associated with light guiding in an optical fiber can be used for highly sensitive and selective biochemical affinity assays [11]. Due to the small penetration depth of the evanescent field into the medium, the generation and detection of luminescence are restricted to the close proximity of the fiber core, i.e., fluorophores in solution beyond the evanescent field will not contribute to the emission signal. Evanescent wave sensors allow the binding of fluorophores to the sensor surface to be monitored in real-time mode. These advantages make this approach especially useful for the determination of substances in complex media, such as blood, river water or soil extracts. An EWFI for the detection of the herbicide Atrazine has been developed.

In [7] Vtg as a sensitive biomarker for environmental estrogens is investigated. In this study, an immunosensor for quantifying zebra fish Vtg was developed using the Octet system. First, protein A sensors were immobilized with purified anti-lipovitellin (Lv) antibody that demonstrated specificity to Vtg. Then, antibody-coated biosensors were immersed into zebra fish Lv standards and diluted samples. The Octet system measured and recorded kinetic parameters between antigens and captured antibody within $5 \mathrm{~min}$. Sample Vtg concentrations were automatically calculated by interpolating relative binding rates observed with each sample and the immobilized antiLv antibody into the developed standard curve. The sensor arrays exhibited a wide line arrange from 78 to $5000 \mathrm{ng} / \mathrm{mL}$, and the inter-assay coefficient to variation was $0.66-1.97 \%$.

One of the most interesting approaches in the field of optical biosensors is the possibility to combine the high sensitivity of laser detection with the high selectivity provided by specific interactions. Furthermore, the addition of nanomaterials to these sensors had provided additional advantages to the development to bioanalytical system. In [21] they provided a critical perspective on these approaches and their advantages / limitations for improving the performance and detection of laser-coupled immunosensors. Here we can find examples relevant to the environmental, clinical, and toxicological fields.

Conclusions. So, were searched the basic principles of design and physical and biological methods of use of optical immunosensors. We investigated the main application of optical immunosensors in biology and medicine including testing food quality, natural environment protection, medical diagnostics. 
Among the plans for the future in the field of biosensor development, we indicate, among others, the necessity of implanting small chips placed on the human body in order to control vital functions, correct irregularities or signal sudden situations requiring quick intervention. It seems that further progress in the field of biosensorics will contribute to the effective protect against cancer.

\section{Література.}

1. Acousto-optictunable filter-surface plasmon resonance immunosensor for fibronectin / Y. Tian, Y. Chen, D. Song [et al.] // Analytica Chimica Acta. — 2005. — Vol. 551, No. 1-2. - P. 98-104.

2. A label-free cardiac biomarker immunosensor based on phase-shifted microfiber Bragg grating / T. Liu, L. L. Liang, P. Xiao [et al.] // Biosensors and Bioelectronics. - 2018. - Vol. 100. - P. 155-160.

3. A label-free porous alumina interferometric immunosensors / S. Alvarez, C. Li, C. Chiang [et al.] // ASC Nano. — 2009. — Vol. 3. - P. 3301-3307.

4. Analytical, thermodynamical and kinetic characteristics of photoluminescence immunosensor for the determination of Ochratoxin A / R. Viter, M. Savchuk, I. Iatsunskyi [et al.] // Biosensors and Bioelectronics. - 2018. - Vol. 99. - P. 237-243.

5. A non-competitive surface plasmon resonance immunosensor for rapid detection of triazophos residue in environmental and agricultural samples / Y. Guo, R. Liu, Y. Liu [et al.] // Science of The Total Environment. - 2018. - Vol. 613-614. - P. 783-791.

6. Aoyagi S. Development of fluorescence change-based, reagent-less optic immunosensor / S. Aoyagi, M. Kudo // Biosensors and Bioelectronics. - 2005. — Vol. 20, No. 8. - P. 1680-1684.

7. Development of an immunosensor for quantifying zebra fish vitellogenin based on the Octet system / J. Wang, J. Wang, Z. Zhang [et al.] // Analytical Biochemistry. — 2017. - Vol. 533. - P. 60-65.

8. Driscoll A. J. Numerical modeling of analyte diffusion and adsorption behavior in microparticle and nanoparticle based biosensors / A. J. Driscoll, P. A. Johnson // Chemical Engineering Science. - 2018. — Vol. 184. - P. 141-148.

9. Establishment of evanescent wave fiber-optic immunosensor method for detection bluetongue virus / H. Yin, R. Xiao, Z. Rong [et al.] // Methods. — 2015. — Vol. 90. - P. 65-67.

10. Fabry - Perot fiber-optic immunosensor based on suspended layer-by-layer (chitosan / polystyrene sulfonate) membrane / L. H. Chen, C. C. Chan, R. Menon [et al.] // Sensors and Actuators B: Chemical. - 2013. - Vol. 188. - P. 185-192.

11. Fiber-optic Atrazine immunosensor / P. Oroszlan, G. L. Duveneck, M. Ehrat, H. M. Widmer // Sensors and
Actuators B: Chemical. - 1993. - Vol. 11, No. 1-3. - P. 301-305.

12. Fiber-optic-based immunosensors for haptens / T. A. Betts, G. C. Catena, J. Huang [et al.] // Analytica Chimica Acta. - 1991. - Vol. 246, No. 1. - P. 55-63.

13. Fiber optic immunosensors based on enhanced chemiluminescence and their application to determine different antigens / N. F. Starodub, P. J. Arenkov, A. N. Starodub, V. A. Berezin // Sensors and Actuators B: Chemical. — 1994. - Vol. 18, No. 1-3. - P. 161-165.

14. Gaudin V. Advances in biosensor development for the screening of antibiotic residues in food products of animal origin - A comprehensive review / V. Gaudin // Biosensors and Bioelectronics. — 2017. — Vol. 90. - P. 363-377.

15. Kłos-Witkowska A. The phenomenon of fluorescence inimmunosensors / A. Kłos-Witkowska // Acta Biochimica Polonica. 2016. - Vol. 63, No. 2. P. 215-221.

16. Label-free fiber-optic interferometric immunosensors based on waist-enlarged fusion taper // L. H. Chen, C. C. Chan, K. Ni [et al.] // Sensors and Actuators B: Chemical. - 2013. - Vol. 178. - P. 176-184.

17. Martsenyuk V. P. Stability, bifurcation and transition to chaos in a model of immunosens or based on lattice differential equations with delay / V. P. Martsenyuk, A. Klos-Witkowska, A. S. Sverstyuk // Electronic Journal of Qualitative Theory of Differential Equations. - 2018. - No. 27. - P. 1-31.

18. Martsenyuk V.P. Study of classification of immunosensors from viewpoint of medical tasks / V. P. Martsenyuk, A. Klos-Witkowska, A. S. Sverstyuk // Medical informatics and engineering. — 2018. — № 1 (41). P. 13-19.

19. Melamine detection in dairy products by using a reusable evanescent wave fiber-optic biosensor / X. Hao, X. Zhou, Y. Zhang [et al.] // Sensors and Actuators B: Chemical. - 2014. — Vol. 204. - P. 682-687.

20. Metal enhanced fluorescence (MEF) for biosensors: General approaches and a review of recent developments / Y. Jeong, Y. M. Kook, K. Lee, W. G. Koh // Biosensors and Bioelectronics. - 2018. - Vol. 111. - P. 102-116.

21. Nanomaterials in fluorescent laser-based immunosensors: Review and applications / P. R. Aranda, G. A. Messina, F. A. Bertolino [et al.] // Microchemical Journal. 2018. - Vol. 141. - P. 308-323.

22. Optical wave quite light-mode spectroscopy immunosensors for environmental monitoring / A. Szekacs, N. Adanyi, I. Szekacs, I. Szendro // Apply Opt. — 2009. — Vol. 48. - P. 151-158.

23. Photoinducible silane diazirine as an effective cross linker in the construction of a chemiluminescent immunosensor targeting a model E. coli analyte / K. Ye, P. D. Sinawang, A. I. Y. Tok, R. S. Marks // Sensors and Actuators B: Chemical. — 2018. — Vol. 256. P. 234-242. 
24. Photonic crystal fiber-based immunosensor for high-performance detection of alphafetoprotein / X. Liu, X. Song, Z. Dong [et al.] // Biosensors and Bioelectronics. — 2017. — Vol. 91. - P. 431-435.

25. Porous silicon based photoluminescence immunosensor for rapid and highly-sensitive detection of Ochratoxin A / V. Myndrul, R. Viter, M. Savchuk [et al.] // Biosensors and Bioelectronics. — 2018. — Vol. 102. — P. 661-667.

26. Portable fiber-optic immunosensor for detection of methsulfuronmethyl / W. L. Xing, L. R. Ma, Z. H. Jiang [et al.] // Talanta. — 2000. — Vol. 52, No. 5. P. 879-883.

27. Ramirez Bojorge N. (2009) The evolution and development of immunosensors for health and environmental monitoring: problems and perspectives / N. Bojorge Ramirez, A. M. Salgado, B. Valdman // Brazilian J. Chem. Eng. — Vol. 26, No. 2. - P. 227-229.

28. Scholten K. A review of implantable biosensors for closed-loop glucose control and other drug delivery applications / K. Scholten, E. Meng // International Journal of Pharmaceutics. — 2018. — Vol. 544, No. 2. - P. 319-334.

29. Shankaran D. Recent advancements in surface plasmon resonance immunosensor for detection of small molecules of biomedical, food, environmental interest / D. Shankaran, H. Gobi, N. Miura // Sensors and Actuators B: Chemical. — 2007. — Vol. 121. — P. 158-177.

30. Sharma A. K. A review of advancements (2007-2017) in plasmonics-based optical fiber sensors / A. K. Sharma, A. K. Pandey, B. Kaur // Optical Fiber Technology. 2018. - Vol. 43. - P. 20-34.

31. Use of a fibreoptic immunosensor for the detection of pesticides / F. F. Bier, W. Stöcklein, M. Böcher [et al.] // Sensors and Actuators B: Chemical. — 1992. — Vol. 7, No. 1-3. - P. 509-512.

\section{References.}

1. Tian, Y., Chen, Y., Song, D., Liu, X., Bi, S., Zhou, X., Cao, Y., \& Zhang, H. (2005). Acousto-optictunable filter-surface plasmon resonance immunosensor for fibronectin. Analytica Chimica Acta, 551(1-2), 98-104. doi: 10.1016/j.aca.2005.07.017.

2. Liu T, Liang L. L., Xiao P., Sun, L. P., Huang, Y. Y., Ran, Y., Jin, L., \& Guan, B. O. (2018). A label-free cardiac biomarker immunosensor based on phase-shifted microfiber Bragg grating. Biosensors and Bioelectronics, 100, 155-160. doi: 10.1016/j.bios.2017.08.061.

3. Alvarez, S., Li, C., Chiang, C., Shuller, I., \& Sailor, M. (2009). A label-free porous alumina interferometric immunosensors. ASC Nano, 3, 3301-3307. doi: 10.1021/ nn900825q.

4. Viter, R., Savchuk, M., Iatsunskyi, I., Pietralik, Z., Starodub, N., Shpyrka, N., Ramanaviciene, A., Ramanavicius, A. (2018). Analytical, thermodynamical and kinetic characteristics of photoluminescence immunosensor for the determination of Ochratoxin A. Biosensors and Bioelectronics, 99, 237-243. doi: 10.1016/j.bios.2017.07.056.

5. Guo, Y., Liu, R., Liu, Y., Xiang, D., Liu, Y., Gui, W., Li, M., \& Zhu, G. (2018). A non-competitive surface plasmon resonance immunosensor for rapid detection of triazophos residue in environmental and agricultural samples. Science of The Total Environment, 613-614, 783-791. oi: 10.1016/j.scitotenv.2017.09.157.

6. Aoyagi, S., \& Kudo, M. (2005). Development of fluorescence change-based, reagent-less optic immunosensor. Biosensors and Bioelectronics, 20(8), 1680-1684. doi: 10.1016/j.bios.2004.06.041.

7. Wang, J., Wang, J., Zhang, Z., Zhang, X., Ru, S., \& Dong, Y. F. (2017). Development of an immunosensor for quantifying zebra fish vitellogenin based on the Octet system. Analytical Biochemistry, 533, 60-65. doi: 10.1016/j.ab.2017.07.005.

8. Driscoll, A. J., \& Johnson, P. A. (2018). Numerical modeling of analyte diffusion and adsorption behavior in microparticle and nanoparticle based biosensors. Chemical Engineering Science, 184, 141-148. doi: 10.1016/j.ces.2018.03.010.

9. Yin, H., Xiao, R., Rong, Z., Jin, P., Ji, C., \& Zhang, J. (2015). Establishment of evanescent wave fiber-optic immunosensor method for detection bluetongue virus. Methods, 90, 65-67. doi: 10.1016/j.ymeth.2015.05.007.

10. Chen, L. H., Chan, C. C., Menon, R., Balamurali, P., Wong, W. C., Ang, X. M., ... Leong, K. C. (2013). Fabry - Perot fiber-optic immunosensor based on suspended layer-by-layer (chitosan / polystyrene sulfonate) membrane. Sensors and Actuators B: Chemical, 188, 185-192. doi: 10.1016/j.snb.2013.06.093.

11. Oroszlan, P., Duveneck, G. L., Ehrat, M., \& Widmer, H. M. (1993). Fiber-optic Atrazine immunosensor. Sensors and Actuators B: Chemical, 11(1-3), 301-305. doi: 10.1016/0925-4005(93)85268-F.

12. Betts, T. A., Catena, G. C., Huang, J., Litwiler, K. S., Zhang, J., Zagrobelny, J. A., \& Bright, F. V. (1991). Fiber-optic-based immunosensors for haptens. Analytica Chimica Acta, 246(1), 55-63. doi: 10.1016/S00032670(00)80664-9.

13. Starodub, N. F., Arenkov, P. J., Starodub, A. N., \& Berezin, V.A. (1994). Fiber optic immunosensors based on enhanced chemiluminescence and their application to determine different antigens. Sensors and Actuators B: Chemical, 18(1-3), 161-165. doi: 10.1016/09254005(94)87076-4.

14. Gaudin, V. (2017). Advances in biosensor development for the screening of antibiotic residues in food products of animal origin - A comprehensive review. Biosensors and Bioelectronics, 90, 363-377. doi: 10.1016/j. bios.2016.12.005.

15. Kłos-Witkowska, A. (2016). The phenomenon of fluorescence inimmunosensors. Acta Biochimica Polonica, 63(2), 215-221, doi: 10.18388/abp.2015_1231. 
16. Chen, L. H., Chan, C. C., Ni, K., Hu, P. B., Li, T., Wong, W. C., ... Leong, K. C. (2013). Label-free fiber-optic interferometric immunosensors based on waist-enlarged fusion taper. Sensors and Actuators B: Chemical, 178, 176-184. doi: 10.1016/j.snb.2012.12.071.

17. Martsenyuk, V. P., Klos-Witkowska, A., \& Sverstyuk, A. S. (2018). Stability, bifurcation and transition to chaos in a model of immunosens or based on lattice differential equations with delay. Electronic Journal of Qualitative Theory of Differential Equations, 27, 1-31. doi: 10.14232/ejqtde.

18. Martsenyuk, V. P., Klos-Witkowska, A., \& Sverstyuk, A. S. (2018). Study of classification of immunosensors from viewpoint of medical tasks. Medical informatics and engineering, 1(41), 13-19. doi: 10.11603/mie.19961960.2018.1.8887.

19. Hao, X., Zhou, X., Zhang, Y., Liu, L., Long, F., Song, L., \& Shi, H. (2014). Melamine detection in dairy products by using a reusable evanescent wave fiberoptic biosensor. Sensors and Actuators B: Chemical, 204, 682-687. doi: 10.1016/j.snb.2014.08.023.

20. Jeong, Y., Kook, Y. M., Lee, K., \& Koh, W. G. (2018). Metal enhanced fluorescence (MEF) for biosensors: General approaches and a review of recent developments. Biosensors and Bioelectronics, 111, 102-116. doi: 10.1016/j.bios.2018.04.007.

21. Aranda, P. R., Messina, G. A., Bertolino, F. A., Pereira, S. V., Fernández Baldo, M. A., \& Raba, J. (2018). Nanomaterials in fluorescent laser-based immunosensors: Review and applications. Microchemical Journal, 141, 308-323. doi: 10.1016/j.microc.2018.05.024.

22. Szekacs, A., Adanyi, N., Szekacs, I., \& Szendro, I. (2009). Optical wave quite light-mode spectroscopy immunosensors for environmental monitoring. Apply Opt., 48, 151-158. doi: 10.1364/ AO.48.00B151.

23. Ye, K., Sinawang, P. D., Tok, A. I. Y., \& Marks, R. S. (2018). Photoinducibles ilanediazirineasan effective crosslinker in the construction of a chemiluminescent immunosensor targeting a model E. coli analyte. Sensors and Actuators B: Chemical, 256, 234-242. doi: 10.1016/j.snb.2017.10.058.

24. Liu, X., Song, X., Dong, Z., Meng, X., Chen, Y., \& Yang, L. (2017). Photonic crystal fiber-based immunosensor for high-performance detection of alphafetoprotein. Biosensors and Bioelectronics, 91, 431-435. doi: 10.1016/j.bios.2016.12.058.

25. Myndrul, V., Viter, R., Savchuk, M., Shpyrka, N., Erts, D., ... Iatsunskyi, I. (2018). Porous silicon based photoluminescence immunosensor for rapid and highly-sensitive detection of Ochratoxin A. Biosensors and Bioelectronics, 102, 661-667. doi: 10.1016/j. bios.2017.11.048.

26. Xing, W. L., Ma, L. R., Jiang, Z. H., Cao, F. H., \& Jia, M. H. (2000). Portable fiber-optic immunosensor for detection of methsulfuronmethyl. Talanta, 52(5), 879-883. doi: 10.1016/S0039-9140(00)00440-9.
27. Ramirez, B., Salgado, A., \& Valdman, B. (2009). The evolution and development of immunosensors for health and environmental monitoring: problems and perspectives. Brazilian J. Chem Eng., 26, 227-229.

28. Scholten, K., \& Meng, E. (2018). A review of implantable biosensors for closed-loop glucose control and other drug delivery applications. International Journal of Pharmaceutics, 544(2), 319-334, doi: 10.1016/j. ijpharm.2018.02.022.

29. Shankaran, D., Gobi, H., \& Miura, N. (2007). Recent advancements in surface plasmon resonance immunosensor for detection of small molecules of biomedical, food, enviromnetal interst. Sensors and Actuators B: Chemical, 121, 158-177. doi: 10.1016/j. snb.2006.09.014.

30. Sharma, A. K., Pandey, A. K., \& Kaur, B. (2018). A review of advancements (2007-2017) in plasmonicsbased optical fiber sensors. Optical Fiber Technology, 43, 20-34. doi: 10.1016/j.yofte.2018.03.008.

31. Bier, F. F., Stöcklein, W., Böcher, M., Bilitewski, U., \& Schmid, R. D. (1992). Use of a fibreoptic immunosensor for the detection of pesticides. Sensors and Actuators B: Chemical, 7(1-3), 509-512. doi: 10.1016/09254005(92)80354-Z. 